DEMOCRACY AND AUTHORITARIANISM IN INDONESIA AND MALAYSIA 
This page intentionally left blank 


\section{Democracy and Authoritarianism in Indonesia and Malaysia}

\section{The Rise of the Post-Colonial State}

Syed Farid Alatas

Lecturer, Department of Sociology

National University of Singapore

Singapore

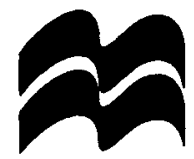


First published in Great Britain 1997 by

MACMILLAN PRESS LTD

Houndmills, Basingstoke, Hampshire RG21 6XS and London

Companies and representatives throughout the world

A catalogue record for this book is available from the British Library.

ISBN 978-1-349-40274-8 ISBN 978-0-230-37854-4 (eBook)

DOI $10.1057 / 9780230378544$

First published in the United States of America 1997 by

ST. MARTIN'S PRESS, INC.,

Scholarly and Reference Division,

175 Fifth Avenue, New York, N.Y. 10010

ISBN 978-0-312-17661-7

Library of Congress Cataloging-in-Publication Data

Alatas, Farid, Syed.

Democracy and authoritarianism in Indonesia and Malaysia : the

rise of the post-colonial state / Syed Farid Alatas.

p. $\mathrm{cm}$.

Includes bibliographical references and index.

ISBN 978-0-312-17661-7 (cloth)

1. Indonesia-Politics and governmen-1950-1966. 2. Indonesia-

-Politics and government-1966-3. Indonesia-Colonial influence.

4. Authoritarianism--Indonesia. 5. Malaysia-Politics and

government. 6. Malaysia-Colonial influence. 7. Democracy-

-Malaysia. 1. Title.

JQ776.A43 1997

$320.9595^{\prime} 09^{\prime} 045-\mathrm{dc} 21$

$97-17009$

CIP

(c) Syed Farid Alatas 1997

Softcover reprint of the hardcover 1st edition 1997 978-0-333-71105-7

All rights reserved. No reproduction, copy or transmission of this publication may be made without written permission.

No paragraph of this publication may be reproduced, copied or transmitted save with written permission or in accordance with the provisions of the Copyright, Designs and Patents Act 1988, or under the terms of any licence permitting limited copying issued by the Copyright Licensing Agency, 90 Tottenham Court Road, London WIP 9HE.

Any person who does any unauthorised act in relation to this publication may be liable to criminal prosecution and civil claims for damages.

The author has asserted his right to be identified as the author of this work in accordance with the Copyright, Designs and Patents Act 1988.

This book is printed on paper suitable for recycling and made from fully managed and sustained forest sources.

$\begin{array}{lllllllll}10 & 9 & 8 & 7 & 6 & 5 & 4 & 3 & 2\end{array}$

$\begin{array}{llllllll}06 & 05 & 04 & 03 & 02 & 01 & 00 & 99\end{array}$ 
To my parents

Syed Hussein Alatas and S. Zaharah Alatas

who give me much love, encouragement and support 
This page intentionally left blank 


\section{Contents}

List of Tables $\quad$ ix

Preface $\quad x$

Acknowledgements $\quad$ xii

1 Post-colonial Discourse on the State in Indonesia and Malaysia 1

The State in Indonesia and Malaysia 1

The Precarious Nature of Democracy in Southeast Asia 7

The Process of Democratization 9

Leadership Succession $\quad 10$

The State in Indonesian and Malaysian Studies 13

Post-colonial State Formation: Indonesia and Malaysia 16

2 Theories of Democratic and Authoritarian State Formation 19

Approaches to the Study of Democracy and Authoritarianism 19

Theories of the Capitalist State 23

Theoretical Perspectives on the State in the Third World 27

The Post-colonial State 34

The Theoretical Perspective of this Study 38

3 Economy and Society in the Pre-independence

Malay-Indonesian World: An Overview 43

Islamization and the Creation of a Muslim Cultural Entity 43

Pre-capitalist Modes of Production 44

Colonial Economy and Society $\quad 54$

$\begin{array}{ll}\text { Conclusion } & 68\end{array}$

4 Peasant and Labour Opposition to the Colonial and

$\begin{array}{ll}\text { Post-colonial State } & 70\end{array}$

Peasants and Mass Movements $\quad 70$

The Typology of Peasants and Their Potential for

Revolution 
Economic Conditions and Peasants Against the Colonial State

Peasants, Labour and Formal Independence $\quad 78$

Armed Rebellions in Indonesia and Malaya 82

The Causes of the Non-revolutionary Nature of the

Peasantry and Labour

5 Nationalism and the Struggle for Democracy

Class, Race, Ideological Orientations and the Nationalist Impulse

Japanese Occupation and Further Developments in Nationalism

Forms of Nationalism in British Malaya and the Netherlands Indies

Internal State Strength and the Birth of Two Democracies

Ethnicity and the Internal Strength of the State

6 From Democracy to Authoritarianism: Tendencies and Transformations

The Parting of Ways

The Failure of Private Capital

The Trials of State Capitalism

Elite Cohesion and Democratic Stability

7 Historical Analysis and the Future of Democracy

Historical Comparative Studies versus Quantitative Cross-national Research

The Future of Democracy in Indonesia and Malaysia 


\section{List of Tables}

2.1 Gross domestic product per capita (\$US) 28

2.2 Debits on investment income per capita (millions \$US) 30

2.3 External public debt per capita (millions current \$US) 30

2.4 Foreign property as a percentage of GDP 31

2.5 Export partner concentration 31

2.6 Government revenue as a percentage of GDP

7.1 Measures of democracy for Indonesia and Malaysia $\quad 160$

7.2 Central government revenue (\% GDP) 162 


\section{Preface}

This work on democratic and authoritarian post-colonial states is based on an historical study of the emergence of the dominant forces that shaped the types of regimes found in Malaysia and Indonesia. Both emerged as democratic post-colonial states. However, in Indonesia the democratic process was suspended altogether and after about a decade of independence, an authoritarian state emerged. Meanwhile, Malaysia still retains, comparatively speaking, a functioning democratic system. The contrast between Indonesia and Malaysia, then, is an opportunity to study the conditions under which democracy can be sustained in post-colonial states.

The study provides an empirical field on which to examine the origins of the post-colonial state. The Indonesian and Malaysian cases exemplify two paths that led to authoritarian and democratic states respectively. These cases offer two very different origins of post-colonial states upon which theoretical issues generated by the literature can be brought to bear. The reason for their selection is that the region consisting of what is today known as Indonesia and Malaysia was historically a cultural entity with similar notions of statecraft, religions and language. I will attempt to show that factors such as the level of economic development and modes of colonial administration, must be ruled out as explanations of different post-colonial state forms in these two countries.

This study, in searching for an alternative explanation, looks at how the interplay of three factors, that is, the elite cohesion, internal state strength and armed resistance, led to two different outcomes, that is, authoritarian and democratic post-colonial states.

Three conditions under which democracy can survive in post-colonial states, based on the experience of Malaysia and Indonesia, are (1) the absence of armed resistance against the state, (2) the presence of an internally strong state, and (3) a high degree of elite cohesion.

The imposition of colonialism upon the pre-capitalist societies of Malaysia and Indonesia left several classes and groups with competing interests in these countries upon formal independence. It is against this historical backdrop that the above factors are examined. It is held that the absence of armed resistance, the presence of an internally strong state and a high degree of elite cohesion led to democratic outcomes, 
as in Malaysia, while armed resistance in the context of a weak state and elite factionalism led to authoritarian outcomes, as in Indonesia. In this way, two different paths to state forms can be, as it were, mapped.

The theoretical perspective of this study, therefore, focuses on the class composition of the state and the dominant elite. Given that both Malaysia and Indonesia emerged as democratic post-colonial states, the reasons for the struggling persistence of democracy in one and its failure in the other have mainly to do with a relatively stronger state and a higher degree of elite cohesion in Malaysia as compared to Indonesia. In addition to regional instability and communist insurgency, the greatest opposition and obstacle to parliamentary democracy came from the elite itself in Indonesia. Democracy was introduced to Indonesia and Malaysia by the Europeans. In such circumstances, democracy can survive only if certain conditions are fulfilled. All three of the above conditions were fulfilled in Malaysia and Indonesia during and immediately following formal independence. However, in Indonesia a decade after independence, the internally weak state took its toll on democracy. The democratic phase of the Indonesian state failed to solve pressing economic problems and state elites were divided as to the course that should be taken. This culminated in the rise to power of anti-democratic forces. In Malaysia, the political elite were never divided to the extent that the democratic nature of the state was undermined for the long term.

The significance of this study lies in the fact that there has not been any comparative work done on the state in Malaysia and Indonesia. Furthermore, the few works on the state in the two countries tend to focus on issues not directly related to the question of the origins of the post-colonial state. Democracy in post-colonial states was introduced from without. What needs explanation is how and why democracy persisted in some post-colonial states and gave way to authoritarianism in others. This study is an effort in this direction. 


\section{Acknowledgements}

An earlier version of this work took the form of a Ph.D. dissertation which was submitted in 1991 to the Department of Sociology. The Johns Hopkins University. I would like to express my gratitude to my doctoral committee consisting of Professors Christopher Chase-Dunn and Stephen Bunker for their comments, suggestions and criticisms. Professor Chase-Dunn as chairman was extremely helpful and encouraging during the various stages of this work.

I would also like to thank Professor Alejandro Portes who offered useful comments during an early stage of the project and Professor Andy Cherlin who was kind enough to advise me when I began postgraduate training at the Johns Hopkins University. Not to be forgotten are the non-academic staff of the University's Department of Sociology, Binnie, Shirley and Pam who provided much technical and moral support while I was at Hopkins.

The dissertation took its final form after I had joined the University of Malaya as a lecturer in 1989, where I was fortunate to have been able to discuss some points with Professors $J$. Kathirithamby-Wells and Lim Teck Ghee. I also wish to thank Professor K. S. Jomo who made the computer facilities of the Institute of Advanced Studies at the University available to me, and the staff of the Main Library at the University, for their very kind assistance. I would also like to thank Mr Julio Andrews, Asia Foundation, Kuala Lumpur, for a travel grant that enabled me to spend a couple of weeks on a field trip in Jakarta in June 1991.

The Department of Sociology, National University of Singapore, provided a conducive working environment while the dissertation was being turned into this book. Also, of great help to me was Ms Dahlia Shamsuddin at the Reference and Information Services, as well as other library staff at the Central Library, National University of Singapore.

I owe a special debt of gratitude to my parents and to Babsy for their enthusiasm and many forms of support throughout my period of study and after.

Finally, I wish to thank my wife Mojgan, who provided much encouragement over many years, and whose love and optimism has sustained me through the years. The arrival of our children, Imad and Afra, has only enhanced the atmosphere of delight and joy in which I work. 